\title{
A New Homostilbene and Two New Homoisoflavones from the Bulbs of Scilla scilloides
}

\author{
Yoichiro Nishida, ${ }^{a}$ Masashi Eto, ${ }^{b}$ Hiroyuki MiYashita,${ }^{c}$ Tsuyoshi Ikeda, ${ }^{c}$ Koki Yamaguchi, ${ }^{d}$ \\ Hitoshi Yoshimitsu, ${ }^{d}$ Toshihiro Nohara, ${ }^{d}$ and Masateru ONO ${ }^{*, b}$ \\ ${ }^{a}$ Aso Pharmaceutical Co., Ltd.; 91-1 Tsukure, Kikuyo, Kumamoto 869-1101, Japan: ${ }^{b}$ Tokai University School of \\ Agriculture; 5435 Minamiaso, Aso, Kumamoto 869-1404, Japan: ${ }^{c}$ Faculty of Medical and Pharmaceutical Sciences, \\ Kumamoto University; 5-1 Oe-honmachi, Kumamoto 862-0973, Japan: and ${ }^{d}$ Faculty of Pharmaceutical Sciences, Sojo \\ University; 4-22-2 Ikeda, Kumamoto 860-0082, Japan. Received February 19, 2008; accepted April 5, 2008
}

A new homostilbene, named scillabene A (2), and two new homoisoflavones, named scillavones A (3) and B (4), were isolated from the bulbs of Scilla scilloides DRUCE (Liliaceae) along with 13 known compounds comprising a homostilbene, seven homoisoflavones, a xanthone, a lignan, and three nortriterpenes. The structures of 2-4 were characterized as 3,5,4'-trihydroxy-3'-methoxy-4-methyl-trans-stilbene, (3R)-5,7,2' -trihydroxy-3',4'dimethoxyspiro\{2H-1-benzopyran-7'-bicyclo[4,2,0]octa[1,3,5]-trien\}-4-one and (3S)-3-(3,4-dihydroxybenzyl)-5hydroxy-6,7-dimethoxychroman-4-one, respectively, on the basis of spectroscopic data and X-ray crystallographic analysis.

Key words Scilla scilloides; homostilbene; homoisoflavone; xanthone; lignan; Liliaceae

Scilla scilloides DRUCE is a perennial herb belonging to the Liliaceae family. This plant has been used as a foodstuff and a traditional medicine for promoting blood circulation, as an antiinflammatory agent, and as an analgesic. ${ }^{1)}$ With regard to the chemical constituents of this bulb, the presence of homoisoflavones and nortriterpenes has been previously reported. $^{2-6)}$ The present paper describes the isolation and structural elucidation of a new homostilbene and two new homoisoflavones from the fresh bulbs of $S$. scilloides along with 13 known compounds comprising a homostilbene, seven homoisoflavones, a xanthone, a lignan, and three nortriterpenes.

The $\mathrm{MeOH}$ extract of the fresh bulbs of $S$. scilloides was suspended in $\mathrm{H}_{2} \mathrm{O}$ and extracted with EtOAc. The EtOAc extract was successively subjected to silica gel, Chromatorex ODS, and Sephadex LH-20 column chromatography as well as HPLC on ODS and silica gel to afford 16 compounds (116) (Fig. 1).

Compounds 5-16 were identified as 5,7,3' -trihydroxy-4' methoxyspiro $\left\{2 H\right.$-1-benzopyran- $7^{\prime}$-bicyclo[4,2,0]octa[1,3,5]trien -4-one (5), ${ }^{7}$ 3,9-dihydroeucomnalin (6), ${ }^{8)}$ 3-(3,4-dihydroxybenzyl)-5,7-dihydroxy-6-methoxychroman-4-one (7), 3-(4-hydroxybenzylidene)-5,7-dihydroxychroman-4-one (8), 9) 3-(3,4-dihydroxybenzylidene)-5,7-dihydroxy-6-methoxychroman-4-one $(9),{ }^{10)}$ scillascillin (10), ${ }^{11)}$ 2-hydroxy-scillascillin (11) ${ }^{12)}$ 1,6-dihydroxy-3-methoxy-8-methylxanthone (12), ${ }^{13)}$ pinoresinol (13), ${ }^{14)}$ 3-dehydro-15-deoxoeucosterol (14), ${ }^{4)}$ 15-deoxoeucosterol (15), ${ }^{4)}$ and 30-hydroxy-15-deoxoeucosterol (16), ${ }^{4)}$ respectively, based on their physical and spectral data, although ${ }^{1} \mathrm{H}$ - and ${ }^{13} \mathrm{C}-\mathrm{NMR}$ spectral data in dimethylsulfoxide (DMSO)- $d_{6}$ of $5,7,8,11$, and 12 , and ${ }^{13} \mathrm{C}$ NMR data in DMSO- $d_{6}$ of $\mathbf{1 0}$ have not been reported in the literature (Fig. 1).

Compound 1 was obtained as an amorphous powder, and its EI-MS gave an $[\mathrm{M}]^{+}$ion peak at $m / z$ 242. The molecular formula of 1 was analyzed as $\mathrm{C}_{18} \mathrm{H}_{14} \mathrm{O}_{3}$ using high-resolution (HR)-EI-MS. The ${ }^{1} \mathrm{H}-\mathrm{NMR}$ spectrum of $\mathbf{1}$ showed signals due to four aromatic protons for an $\mathrm{A}_{2} \mathrm{~B}_{2}$ pattern $[\delta 7.38(2 \mathrm{H}$, d, $J=8.5 \mathrm{~Hz}), 6.75(2 \mathrm{H}, \mathrm{d}, J=8.5 \mathrm{~Hz})]$, two equivalent aro- matic protons $[\delta 6.46(2 \mathrm{H}, \mathrm{s})]$, two trans-coupled olefinic protons $[\delta 6.82(\mathrm{~d}, J=16.0 \mathrm{~Hz}), 6.77(\mathrm{~d}, J=16.0 \mathrm{~Hz})]$, one tertiary methyl group $(\delta 1.93)$, and three hydroxyl groups $[\delta$ $9.53(1 \mathrm{H}, \mathrm{s}), 9.09(2 \mathrm{H}, \mathrm{s})]$. The ${ }^{13} \mathrm{C}-\mathrm{NMR}$ spectrum of 1 exhibited signals due to 14 olefinic carbons $[\delta 157.0,156.2(\times 2)$, $135.1,128.1,127.5(\times 2), 126.7,125.8,115.4(\times 2), 109.8$, $104.0(\times 2)]$ and one methyl carbon $(\delta 8.5)$. These ${ }^{1} \mathrm{H}$ - and ${ }^{13} \mathrm{C}$-NMR signals were assigned with the aid of heteronuclear multiple-quantum coherence (HMQC) and heteronuclear multiple-bond correlation (HMBC) spectra, which indicated correlations between the respective carbons and protons, as shown in Fig. 2. Accordingly, 1 was characterized as 3,5,4'trihydroxy-4-methyl-trans-stilbene, which was recently synthesized and named 4-methylresveratrol, ${ }^{15)}$ although the iso-
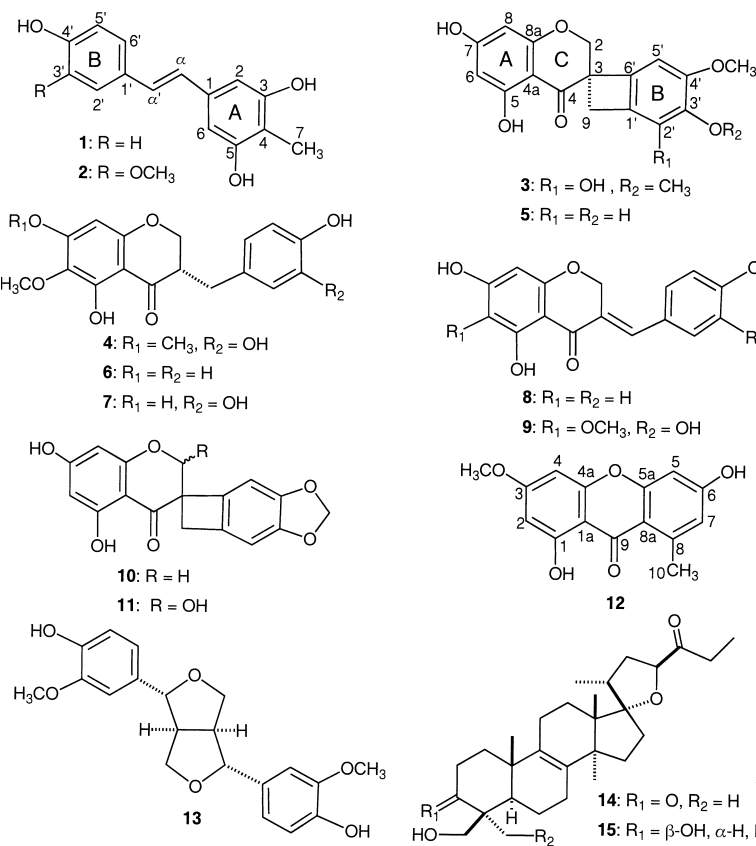
5: $R_{1}=R_{2}=H$
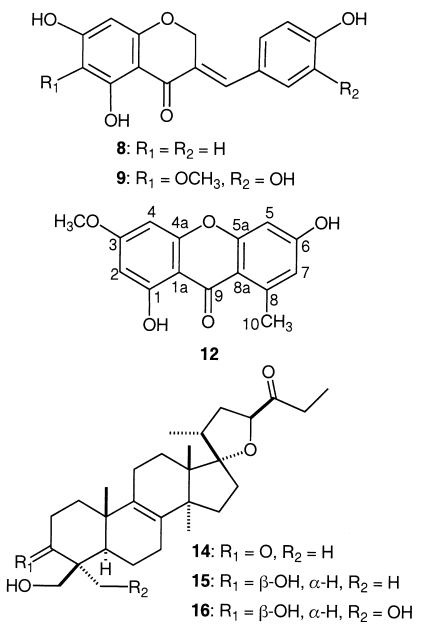

Fig. 1. Structures of $\mathbf{1}-\mathbf{1 6}$ 

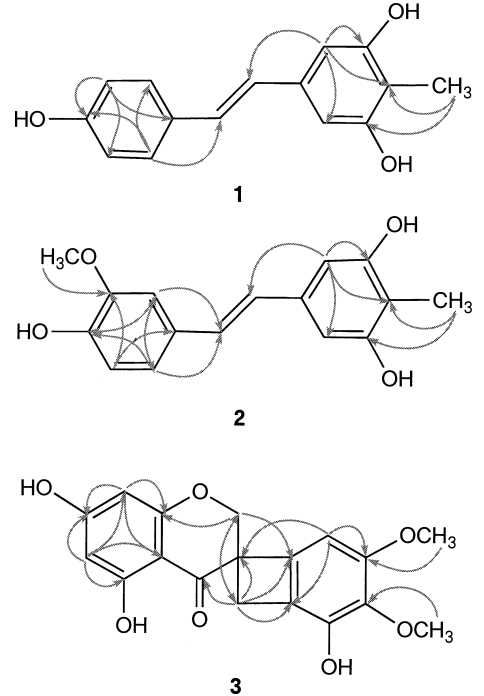

Fig. 2. ${ }^{1} \mathrm{H}-{ }^{13} \mathrm{C}$ Long-Range Correlations Observed for $\mathbf{1}-\mathbf{3}$ in the HMBC Spectra (in DMSO- $d_{6}, 500 \mathrm{MHz}$ )

lation of $\mathbf{1}$ as natural product is reported here for the first time. The ${ }^{1} \mathrm{H}-\mathrm{NMR}$ data of the reported 4-methylresveratrol were similar to those of $\mathbf{1}$, but its ${ }^{13} \mathrm{C}$-NMR data were different from those of $\mathbf{1} .^{15)}$

Compound 2, named scillabene A, was obtained as an amorphous powder. The EI-MS of 2 showed an $[\mathrm{M}]^{+}$ion peak at $m / z 272$, which was 30 mass units $\left[\mathrm{OCH}_{3}-\mathrm{H}\right]$ larger than that of $\mathbf{1}$, and the molecular formula of $\mathbf{2}$ was determined to be $\mathrm{C}_{16} \mathrm{H}_{16} \mathrm{O}_{4}$ using HR-EI-MS. The ${ }^{1} \mathrm{H}-\mathrm{NMR}$ spectrum of 2 was similar to that of $\mathbf{1}$, with the exception that signals due to three aromatic protons for an $\mathrm{ABX}$ pattern $[\delta$ $7.16(\mathrm{~d}, J=2.0 \mathrm{~Hz}), 6.94$ (dd, $J=2.0,8.0 \mathrm{~Hz}), 6.75$ (d, $J=8.0$ $\mathrm{Hz})]$ and one methoxyl group ( $\delta 3.83$ ) appeared, and signals assignable to four aromatic protons for an $\mathrm{A}_{2} \mathrm{~B}_{2}$ pattern disappeared. The ${ }^{13} \mathrm{C}-\mathrm{NMR}$ spectrum of 2 was also analogous to that of 1, apart from the resonances of signals due to the Bring moiety and appearance of a signal due to one methoxyl carbon. Finally, the structure of $\mathbf{2}$ was elucidated based on the HMBC spectrum, in which correlations were observed between the respective carbons and protons, as illustrated in Fig. 2. Consequently, the structure of $\mathbf{2}$ was concluded to be 3,5,4'-trihydroxy-3'-methoxy-4-methyl-trans-stilbene.

Compound 3, named scillavone A, was obtained as colorless needles and exhibited an $[\mathrm{M}]^{+}$ion peak at $\mathrm{m} / \mathrm{z} 344$ in the EI-MS; the HR-positive FAB-MS indicated the molecular formula of $\mathbf{3}$ to be $\mathrm{C}_{18} \mathrm{H}_{16} \mathrm{O}_{7}$. The ${ }^{1} \mathrm{H}-\mathrm{NMR}$ spectrum of $\mathbf{3}$, which was similar to that of $\mathbf{5}$ except for the appearance of a signal due to an additional methoxyl group and the lack of that due to an aromatic proton, revealed the presence of signals due to three aromatic protons $[\delta 6.27(\mathrm{~s}), 5.95(\mathrm{~d}, J=$ $2.0 \mathrm{~Hz}), 5.91(\mathrm{~d}, J=2.0 \mathrm{~Hz})]$, two oxygenated methylene protons $[\delta 4.59(\mathrm{~d}, J=11.0 \mathrm{~Hz}), 4.56(\mathrm{~d}, J=11.0 \mathrm{~Hz})]$, two methoxyl groups $(\delta 3.67,3.62)$, and two methylene protons $[\delta 3.35(\mathrm{~d}, J=13.0 \mathrm{~Hz}), 2.93(\mathrm{~d}, J=13.0 \mathrm{~Hz})]$. The ${ }^{13} \mathrm{C}-\mathrm{NMR}$ spectrum, which was assigned using techniques similar to those for 1, was also analogous to that of 5; in particular, the signals due to A- and C-ring moieties were almost superimposable. From these data, 3 was considered to be attached by a methoxyl group to the B-ring moiety of $\mathbf{5}$. This assumption

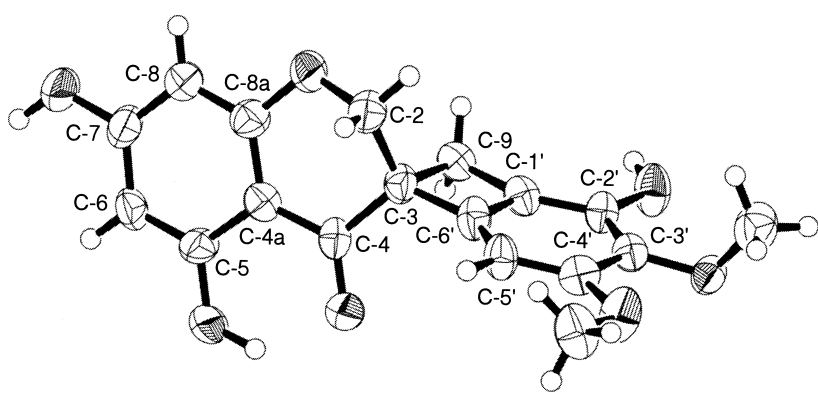

Fig. 3. ORTEP Drawing of $\mathbf{3}$

The ellipsoid probability level of $\mathbf{3}$ is $50 \%$.

was confirmed by the HMBC spectrum, in which correlations were observed between the respective carbons and protons, as illustrated in Fig. 2. However, the locations of methoxyl groups and hydroxyl group in the B-ring moiety could not be confirmed. From the X-ray crystallographic analysis of $\mathbf{3}$, their locations were determined as shown in Fig. 3. Finally, the absolute configuration at C-3 in $\mathbf{3}$ was concluded to be $R$ on the basis of the Cotton curve $\left([\theta]_{295}\right.$ $+22764)$ of the circular dichroism (CD) spectrum. ${ }^{16)}$ Thus 3 was elucidated as $(3 R)-5,7,2^{\prime}$-trihydroxy-3', $4^{\prime}$-dimethoxyspiro $\{2 H$-1-benzopyran-7'-bicyclo[4,2,0]octa[1,3,5]-trien\}-4-one.

Compound 4, named scillavone $\mathrm{B}$, was obtained as an amorphous powder. The EI-MS of 4 indicated an $[\mathrm{M}]^{+}$ion peak at $m / z 346$, and the molecular formula of 4 was defined as $\mathrm{C}_{18} \mathrm{H}_{18} \mathrm{O}_{7}$ by HR-EI-MS. The ${ }^{1} \mathrm{H}-\mathrm{NMR}$ spectrum, which was analogous to that of 7 with an additional signal due to one methoxyl group, gave signals due to four aromatic protons $[\delta 6.66(\mathrm{~d}, J=8.0 \mathrm{~Hz}), 6.62(\mathrm{~d}, J=2.0 \mathrm{~Hz}), 6.48(\mathrm{dd}, J=$ $2.0,8.0 \mathrm{~Hz}), 6.22(\mathrm{~s})]$, two oxygenated methylene protons $[\delta$ 4.29 (dd, $J=4.5,11.5 \mathrm{~Hz}), 4.11(\mathrm{dd}, J=8.0,11.5 \mathrm{~Hz})]$, two methoxyl groups $(\delta 3.84,3.64)$, three aliphatic protons $[\delta \mathrm{ca}$. 2.95, ca. 2.94, $2.51(\mathrm{dd}, J=11.0,14.5 \mathrm{~Hz})]$, and three hydroxyl groups [ $\delta 11.98$ (brs), 8.83 (brs), 8.78 (brs)]. The ${ }^{13} \mathrm{C}-\mathrm{NMR}$ spectrum was also similar to that of 7 , although the resonances of the signals due to the A-ring moiety were slightly different and a signal due to one more methoxyl carbon appeared. From these data, 4 was recognized as a derivative of 7, in which the hydroxyl group at C-7 was methylated. This was confirmed by the difference NOE spectrum, in which a correlation was observed between $\mathrm{H}-8$ and the methoxyl group at $\delta 3.84$. The absolute configuration at C-3 was determined to be $S$ on the basis of a positive Cotton effect $\left([\theta]_{288}+10024\right)$ in the range of $287-295 \mathrm{~nm}$ in the CD curve. ${ }^{17)}$ The structure of $\mathbf{4}$ was therefore defined as (3S)-3(3,4-dihydroxybenzyl)-5-hydroxy-6,7-dimethoxychroman-4one.

To the best of our knowledge, $\mathbf{2}-\mathbf{4}$ are new compounds, and the isolation of $\mathbf{1}, \mathbf{5}, \mathbf{7}-\mathbf{9}$, and $\mathbf{1 1 - 1 3}$ from $S$. scilloides is described here for the first time.

\section{Experimental}

The melting points were determined on a Yanagimoto micromelting point apparatus and are uncorrected. Optical rotations were measured with a Jasco DTP-1000 KUY digital polarimeter. CD spectra were measured on a Jasco J-820 spectrometer. ${ }^{1} \mathrm{H}$ - and ${ }^{13} \mathrm{C}$-NMR spectra were recorded using a JEOL alpha 500 spectrometer at 500 and $125 \mathrm{MHz}$, respectively, and chemical shifts were specified on a $\delta$ (ppm) scale with tetramethylsilane (TMS) as an internal standard. The MS were obtained on a JEOL JMS-DX-303HF instrument. Column chromatography was carried out with silica gel 60 (Art. 
1.09385 and Art. 1.07734, Merck), Sephadex LH-20 (Pharmacia Fine Chemicals), and Chromatorex ODS (Fuji Silysia Chemical Co., Ltd.). HPLC separation was run on a Micro pump LC-10AS (Shimadzu) with an RI-Detector RID-10A (Shimadzu) or a UV detector SPD-10A (Shimadzu). For HPLC column chromatography, Cosmosil 5C18 AR-II $(250 \mathrm{~mm} \times 20 \mathrm{~mm}$ i.d., Nacalai Tesque, Inc.), YMC-pack SIL-06 $(250 \mathrm{~mm} \times 20 \mathrm{~mm}$ i.d., YMC Co., Ltd.), and Cosmosil 5SL-II ( $250 \mathrm{~mm} \times 20 \mathrm{~mm}$ i.d., Nacalai Tesque, Inc.) were used.

Plant Material The fresh bulbs of $S$. scilloides were cultivated in Kumamoto prefecture, Japan, and were harvested in August 2005.

Extraction and Isolation The crushed fresh bulbs of $S$. scilloides $(18.5 \mathrm{~kg})$ were extracted with $\mathrm{MeOH}$ at room temperature, and the solvent was removed under reduced pressure to give a syrup $(3521.7 \mathrm{~g})$. The $\mathrm{MeOH}$ extract was suspended in $\mathrm{H}_{2} \mathrm{O}$ and extracted with EtOAc. A portion $(14.4 \mathrm{~g})$ of the EtOAc extract $(26.4 \mathrm{~g})$ was subjected to silica gel [hexane-acetone (20:1, 10:1, 5:1,3:1,1:1)] chromatography to afford fractions (frs.) $1-$ 11. Fr. $6(428 \mathrm{mg})$ was chromatographed over Chromatorex ODS $(30 \%$ $\mathrm{MeOH}, 40 \% \mathrm{MeOH}, 50 \% \mathrm{MeOH}, 60 \% \mathrm{MeOH}, 80 \% \mathrm{MeOH}, 90 \% \mathrm{MeOH}$, $\mathrm{MeOH})$ to give frs. $6.1-6.13$. Fr. $6.6(113 \mathrm{mg})$ was subjected to HPLC (Cosmosil 5C18 AR-II, 65\% MeOH) to afford fr. 6.6.1 (65 mg), which was

Table $1 . \quad{ }^{1} \mathrm{H}$ - and ${ }^{13} \mathrm{C}-\mathrm{NMR}$ Data for $\mathbf{1}$ and $\mathbf{2}$ (in DMSO- $d_{6}$ )

\begin{tabular}{|c|c|c|c|c|}
\hline & \multicolumn{2}{|l|}{1} & \multicolumn{2}{|l|}{2} \\
\hline & $\delta_{\mathrm{H}}$ & $\delta_{\mathrm{C}}$ & $\delta_{\mathrm{H}}$ & $\delta_{\mathrm{C}}$ \\
\hline 1 & & 135.1 & & 135.2 \\
\hline 2 & $6.46 \mathrm{~s}$ & 104.0 & $6.48 \mathrm{~s}$ & 104.1 \\
\hline 3 & & 156.2 & & 156.2 \\
\hline 4 & & 109.8 & & 109.9 \\
\hline 5 & & 156.2 & & 156.2 \\
\hline 6 & $6.46 \mathrm{~s}$ & 104.0 & $6.48 \mathrm{~s}$ & 104.1 \\
\hline 7 & $1.93 \mathrm{~s}$ & 8.5 & $1.95 \mathrm{~s}$ & 8.5 \\
\hline$\alpha$ & $6.77 \mathrm{~d}(16.0)$ & 125.8 & $6.85 \mathrm{~d}(16.0)$ & 126.1 \\
\hline$\alpha^{\prime}$ & $6.82 \mathrm{~d}(16.0)$ & 126.7 & $6.81 \mathrm{~d}(16.0)$ & 127.0 \\
\hline $1^{\prime}$ & & 128.1 & & 128.7 \\
\hline $2^{\prime}$ & $7.38 \mathrm{~d}(8.5)$ & 127.5 & $7.16 \mathrm{~d}(2.0)$ & 109.8 \\
\hline $3^{\prime}$ & $6.75 \mathrm{~d}(8.5)$ & 115.4 & & 147.8 \\
\hline $4^{\prime}$ & & 157.0 & & 146.4 \\
\hline $5^{\prime}$ & $6.75 \mathrm{~d}(8.5)$ & 115.4 & $6.75 \mathrm{~d}(8.0)$ & 115.5 \\
\hline $6^{\prime}$ & $7.38 \mathrm{~d}(8.5)$ & 127.5 & $6.94 \mathrm{dd}(2.0,8.0)$ & 119.9 \\
\hline $\mathrm{OCH}_{3}$ & & & $3.83 \mathrm{~s}$ & 55.7 \\
\hline $3,5-\mathrm{OH}$ & $9.09 \mathrm{~s}$ & & $9.10 \mathrm{~s}$ & \\
\hline 4-OH & $9.53 \mathrm{~s}$ & & & \\
\hline
\end{tabular}

${ }^{1} \mathrm{H}-\mathrm{NMR}, 500 \mathrm{MHz} ;{ }^{13} \mathrm{C}-\mathrm{NMR}, 125 \mathrm{MHz} . \delta$ in ppm from TMS (coupling constants $(J)$ in $\mathrm{Hz}$ are given in parentheses). finally crystallized from a mixture of hexane and acetone to give $\mathbf{1 0}(16 \mathrm{mg})$. Chromatography of fr. $6.8(29 \mathrm{mg})$ over silica gel $\left[\mathrm{CHCl}_{3}-\mathrm{MeOH}-\mathrm{H}_{2} \mathrm{O}\right.$ $(1: 0: 0,14: 2: 0.1)]$ furnished $12(22 \mathrm{mg})$. Fr. $6.10(86 \mathrm{mg})$ was subjected to silica gel $\left[\mathrm{CHCl}_{3}-\mathrm{MeOH}-\mathrm{H}_{2} \mathrm{O}(1: 0: 0,14: 2: 0.1)\right]$ chromatography to give $14(20 \mathrm{mg})$ and $15(38 \mathrm{mg})$. Fr. $9(1953 \mathrm{mg})$ was chromatographed over Chromatorex ODS $(30 \% \mathrm{MeOH}, 40 \% \mathrm{MeOH}, 50 \% \mathrm{MeOH}, 60 \% \mathrm{MeOH}$, $80 \% \mathrm{MeOH}, 90 \% \mathrm{MeOH}, \mathrm{MeOH})$ to give frs. $9.1-9.11$. Frs. $9.6(156 \mathrm{mg})$, $9.7(166 \mathrm{mg})$, and $9.10(47 \mathrm{mg})$ were each subjected to HPLC [YMC-pack SIL-06, $\left.\mathrm{CHCl}_{3}-\mathrm{MeOH}(50: 1)\right]$ to give $\mathbf{1 3}(6 \mathrm{mg}), \mathbf{2}(20 \mathrm{mg}), 7(30 \mathrm{mg})$, and $\mathbf{1}(7 \mathrm{mg})$ from fr. $9.6,3(203 \mathrm{mg})$ from fr. 9.7 , and $\mathbf{8}(16 \mathrm{mg})$ from fr. 9.10 . Fr. $9.8(655 \mathrm{mg})$ was successively subjected to HPLCs (Cosmosil 5C18 AR-II, $50 \% \mathrm{MeOH}$; YMC-pack SIL-06, $\mathrm{CHCl}_{3}-\mathrm{MeOH}(50: 1)$ in turn) to give 5 (99 mg), 6 (368 mg), 3 (44 mg), and $11(58 \mathrm{mg})$. Fr. 10 (1038 mg) was chromatographed over Chromatorex ODS (30\% MeOH, 35\% MeOH, $40 \%$ $\mathrm{MeOH}, 60 \% \mathrm{MeOH}, 80 \% \mathrm{MeOH}, 90 \% \mathrm{MeOH}, \mathrm{MeOH}$ ) to afford frs. $10.1-$ 10.21. The successive chromatography of fr. $10.7(103 \mathrm{mg})$ over Sephadex LH-20 (MeOH), silica gel [hexane-acetone $(3: 1,2: 1,1: 1,0: 1)]$ and HPLC [YMC-pack SIL-06 and Cosmosil 5SL-II, $\mathrm{CHCl}_{3}: \mathrm{MeOH}: \mathrm{H}_{2} \mathrm{O}$ $(14: 2: 0.1)$ ] gave $7(37 \mathrm{mg})$. HPLC [Cosmosil 5SL-II, hexane-acetone $(2: 1)]$ of fr. $10.11(51 \mathrm{mg})$ afforded $6(6 \mathrm{mg}), 4(4 \mathrm{mg})$, and $9(7 \mathrm{mg})$. Fr. $10.18(39 \mathrm{mg})$ was subjected to Sephadex LH-20 (MeOH) chromatography to furnish $\mathbf{1 6}(25 \mathrm{mg})$.

1: Amorphous powder. EI-MS m/z: $242[\mathrm{M}]^{+}$. HR-EI-MS $m / z$ : 242.0963 (Calcd for $\mathrm{C}_{15} \mathrm{H}_{14} \mathrm{O}_{3}: 242.0943$ ). ${ }^{1} \mathrm{H}$ - and ${ }^{13} \mathrm{C}-\mathrm{NMR}$ spectral data: see Table 1.

2: Amorphous powder. EI-MS $m / z: 272[\mathrm{M}]^{+}$. HR-EI-MS $m / z$ : 272.1055 (Calcd for $\mathrm{C}_{16} \mathrm{H}_{16} \mathrm{O}_{4}: 272.1049$ ). ${ }^{1} \mathrm{H}$ - and ${ }^{13} \mathrm{C}$-NMR spectral data: see Table 1.

3: Colorless needles $\left(\mathrm{MeOH}-\mathrm{H}_{2} \mathrm{O}\right), \mathrm{mp} 222^{\circ} \mathrm{C}$. $[\alpha]_{\mathrm{D}}^{24}+65.6^{\circ}(c=0.5$, DMSO). CD $\left(c=1.0 \times 10^{-4} \mathrm{M}, \mathrm{MeOH}\right)[\theta]_{295}+22764$. EI-MS $m / z: 344[\mathrm{M}]^{+}$, 329. HR-positive FAB-MS $m / z: 345.0917$ (Calcd for $\mathrm{C}_{18} \mathrm{H}_{17} \mathrm{O}_{7}: 345.0975$ ). ${ }^{1} \mathrm{H}-\mathrm{NMR}$ spectral data: see Table $2 .{ }^{13} \mathrm{C}$-NMR spectral data: see Table 3.

4: Amorphous powder. $[\alpha]_{\mathrm{D}}^{28}+17.4^{\circ}(c=1.0$, DMSO $)$. $\mathrm{CD}\left(c=1.0 \times 10^{-4}\right.$ м, $\mathrm{MeOH})[\theta]_{288}+10024$. EI-MS $m / z: 346[\mathrm{M}]^{+}$. HR-EI-MS $m / z: 346.1049$ (Calcd for $\mathrm{C}_{18} \mathrm{H}_{18} \mathrm{O}_{7}: 346.1052$ ). ${ }^{1} \mathrm{H}-\mathrm{NMR}$ spectral data: see Table $2 .{ }^{13} \mathrm{C}$ NMR spectral data: see Table 3 .

12: ${ }^{1} \mathrm{H}-\mathrm{NMR}$ (in DMSO- $\left.d_{6}, 500 \mathrm{MHz}\right) \delta: 13.37(1 \mathrm{H}, \mathrm{s}, \mathrm{OH}-1), 6.63(2 \mathrm{H}$, s, H-5, H-7), $6.64(1 \mathrm{H}, \mathrm{d}, J=2.5 \mathrm{~Hz}, \mathrm{H}-4), 6.26(1 \mathrm{H}, \mathrm{d}, J=2.5 \mathrm{~Hz}, \mathrm{H}-2), 3.84$ $\left(3 \mathrm{H}, \mathrm{s}, \mathrm{OCH}_{3}-3\right), 2.71\left(3 \mathrm{H}, \mathrm{s}, \mathrm{H}_{3}-10\right) .{ }^{13} \mathrm{C}-\mathrm{NMR}$ (in DMSO- $\left.d_{6}, 125 \mathrm{MHz}\right) \delta$ : 181.5 (C-9), 165.5 (C-3), 162.9 (C-1 or C-6), 162.8 (C-6 or C-1), 158.8 (C5a), 156.4 (C-4a), 142.9 (C-8), 116.2 (C-7), 110.8 (C-8a), 103.0 (C-1a), 100.4 (C-5), 96.7 (C-2), 91.9 (C-4), $55.8\left(\mathrm{OCH}_{3}-3\right), 22.9$ (C-10).

Single-Crystal X-Ray Analysis of 3 A colorless needle crystal having approximate dimensions of $0.10 \times 0.20 \times 1.00 \mathrm{~mm}$ was mounted on a glass fiber. All measurements were made on a Rigaku RAXIS RAPID imaging plate area detector with graphite monochromated $\mathrm{MoK} \alpha$ radiation. The data were collected at a temperature of $23 \pm 1^{\circ} \mathrm{C}$ to a maximum $2 \theta$ value of $55.0^{\circ}$. The structures were solved using the direct method (SIR-92), ${ }^{18)}$ and hydrogen atoms were placed at the calculation. A full-matrix least-squares technique was used with anisotropic thermal parameters for nonhydrogen

Table 2. ${ }^{1} \mathrm{H}$-NMR Data for $\mathbf{3}, \mathbf{4}, \mathbf{5}, \mathbf{7 , 8}$ and 11 (in DMSO- $d_{6}, 500 \mathrm{MHz}$ )

\begin{tabular}{|c|c|c|c|c|c|c|}
\hline & 3 & 4 & 5 & 7 & 8 & 11 \\
\hline 2 & $4.59 \mathrm{~d}(11.5)$ & $4.29 \mathrm{dd}(4.5,11.5)$ & $4.59 \mathrm{~d}(11.0)$ & $4.23 \mathrm{dd}(4.5,11.0)$ & $5.34 \mathrm{~d}$ like (2.0) & $5.66 \mathrm{~s}, 5.59 \mathrm{~s}$ \\
\hline 2 & $4.56 \mathrm{~d}(11.5)$ & $4.11 \mathrm{dd}(8.0,11.5)$ & $4.54 \mathrm{~d}(11.0)$ & $4.05 \mathrm{dd}(7.5,11.0)$ & $5.34 \mathrm{~d}$ like (2.0) & \\
\hline 3 & & ca. 2.95 & & $2.90 \mathrm{~m}$ & & \\
\hline 6 & $5.95 \mathrm{~d}(2.0)$ & & $5.96 \mathrm{~d}(2.0)$ & & $5.90 \mathrm{~d}(2.0)$ & 5.96 br s, 5.95 br s \\
\hline 7 & & & & & & \\
\hline 8 & $5.91 \mathrm{~d}(2.0)$ & $6.22 \mathrm{~s}$ & $5.92 \mathrm{~d}(2.0)$ & $5.95 \mathrm{~s}$ & $5.86 \mathrm{~d}(2.0)$ & $5.91 \mathrm{brs}, 5.90 \mathrm{brs}$ \\
\hline 9 & $3.35 \mathrm{~d}(13.0)$ & ca. 2.95 & $3.38 \mathrm{~d}(13.5)$ & $2.94 \mathrm{dd}(5.0,13.5)$ & $7.67 \mathrm{~s}$ & $3.56 \mathrm{~d}(13.5), 3.27 \mathrm{~d}(13.5)$ \\
\hline 9 & $2.93 \mathrm{~d}(13.0)$ & ca. 2.51 & $3.00 \mathrm{~d}(13.5)$ & $2.53 \mathrm{dd}(9.0,13.5)$ & & $3.09 \mathrm{~d}(13.5), 2.94 \mathrm{~d}(13.5)$ \\
\hline $2^{\prime}$ & & $6.62 \mathrm{~d}(2.0)$ & $6.70 \mathrm{~s}^{a)}$ & $6.62 \mathrm{~d}(2.0)$ & $7.32 \mathrm{~d}(8.5)$ & $6.87 \mathrm{~s}, 6.84 \mathrm{~s}$ \\
\hline $3^{\prime}$ & & & & & $6.88 \mathrm{~d}(8.5)$ & \\
\hline $5^{\prime}$ & $6.27 \mathrm{~s}$ & $6.66 \mathrm{~d}(8.0)$ & $6.66 \mathrm{~s}^{a)}$ & $6.67 \mathrm{~d}(8.0)$ & $6.88 \mathrm{~d}(8.5)$ & $6.66 \mathrm{~s}, 6.49 \mathrm{~s}$ \\
\hline $6^{\prime}$ & & $6.48 \mathrm{dd}(2.0,8.0)$ & & $6.48 \mathrm{dd}(2.0,8.0)$ & $7.32 \mathrm{~d}(8.5)$ & \\
\hline $\mathrm{OCH}_{3}$ & $3.67 \mathrm{~s}$ & $3.84 \mathrm{~s}$ & $3.69 \mathrm{~s}$ & $3.67 \mathrm{~s}$ & & \\
\hline $\mathrm{OCH}_{3}$ & $3.62 \mathrm{~s}$ & $3.64 \mathrm{~s}$ & & & & \\
\hline $\mathrm{CH}_{2} \mathrm{OCH}_{2}$ & & & & & & $5.92 \mathrm{~s}$ \\
\hline $5-\mathrm{OH}$ & $12.09 \mathrm{~s}$ & $11.98 \mathrm{~s}$ & $12.13 \mathrm{brs}$ & $12.24 \mathrm{~s}$ & $12.90 \mathrm{~s}$ & $11.96 \mathrm{~s}, 11.80 \mathrm{~s}$ \\
\hline $\mathrm{OH}$ & 10.91 br s & $8.83 \mathrm{brs}$ & & & & \\
\hline $\mathrm{OH}$ & $9.55 \mathrm{~s}$ & $8.78 \mathrm{brs}$ & & & & \\
\hline
\end{tabular}

$\delta$ in ppm from TMS (coupling constants $(J)$ in $\mathrm{Hz}$ are given in parentheses). a) Assignments may be interchanged in each column. 
Table 3. ${ }^{13} \mathrm{C}-\mathrm{NMR}$ Data for 3, 4, 5, 7, 8, 10 and 11 (in DMSO- $d_{6}$, $125 \mathrm{MHz})$

\begin{tabular}{|c|c|c|c|c|c|c|c|}
\hline & 3 & 4 & 5 & 7 & 8 & 10 & 11 \\
\hline 2 & 72.7 & 69.1 & 73.3 & 68.9 & 67.2 & 72.8 & 103.3 \\
\hline 3 & 53.1 & 45.8 & 53.8 & 45.7 & 126.1 & 52.8 & $58.1,57.6$ \\
\hline 4 & 195.7 & 198.9 & 196.5 & 198.4 & 184.3 & 195.9 & $196.1,194.5$ \\
\hline $4 \mathrm{a}$ & 100.8 & 102.1 & 101.1 & 101.3 & 101.7 & 100.9 & $100.5,100.5$ \\
\hline 5 & 163.8 & 154.4 & 164.1 & 155.4 & 164.4 & 163.9 & $163.4,163.3$ \\
\hline 6 & 96.0 & 129.7 & 96.3 & $129.1^{a)}$ & 96.2 & 96.1 & $96.0,95.9$ \\
\hline 7 & 166.7 & 160.6 & 166.9 & 159.5 & 166.8 & 166.8 & $166.9,166.8$ \\
\hline 8 & 94.9 & 91.7 & 95.2 & 94.7 & 94.8 & 94.9 & $99.1,98.7$ \\
\hline $8 \mathrm{a}$ & 163.0 & 158.4 & 163.3 & 157.9 & 161.9 & 163.0 & $159.8,159.7$ \\
\hline 9 & 33.4 & 31.3 & 35.4 & 31.4 & 136.6 & 35.2 & $36.5,31.1$ \\
\hline $1^{\prime}$ & 118.7 & 128.6 & $134.0^{a)}$ & $128.8^{a)}$ & 124.7 & 134.6 & $134.2,133.4$ \\
\hline $2^{\prime}$ & 154.2 & 116.3 & 111.5 & 116.3 & 132.8 & 105.7 & 105.7 \\
\hline $3^{\prime}$ & 146.2 & 145.2 & $148.5^{b)}$ & 145.2 & 115.8 & 146.6 & $146.8,146.5$ \\
\hline $4^{\prime}$ & 137.6 & 143.8 & $148.3^{b)}$ & 143.8 & 159.4 & 147.8 & 147.9 \\
\hline $5^{\prime}$ & 98.6 & 115.6 & 106.9 & 115.6 & 115.8 & 104.1 & $105.2,105.2$ \\
\hline $6^{\prime}$ & 138.5 & 119.7 & $133.8^{a)}$ & 119.7 & 132.8 & 135.5 & $135.7,135.6$ \\
\hline $\mathrm{OCH}_{3}$ & 56.0 & 60.0 & 56.2 & 60.0 & & & \\
\hline $\mathrm{OCH}_{3}$ & 59.8 & 56.3 & & & & & \\
\hline $\mathrm{CH}_{2} \mathrm{OCH}_{2}$ & & & & & & 100.0 & $100.1,100.0$ \\
\hline
\end{tabular}
column.

$\delta$ in ppm from TMS. $a, b)$ Assignments may be interchanged in the same

atoms and a riding model for hydrogen atoms. All calculations were performed using the Crystal Structure ${ }^{19,20}$ crystallographic software package.

3: $\mathrm{C}_{18} \mathrm{H}_{16} \mathrm{O}_{7}, \mathrm{~F} . \mathrm{W} .=344.32$, orthorhombic. The systematic absences of $h 00: h \pm 2 n, 0 k 0: k \pm 2 n, 00 l: l \pm 2 n$ uniquely determine the space group to be: $P 2_{1} 2_{1} 2_{1}$ (\#19). $a=5.4644(9), b=11.627(2), c=25.006(4) \AA, V=1588.8(4) \AA^{3}$, $D c=1.44 \mathrm{~g} \mathrm{~cm}^{-3}, Z=4, R=0.091$ for 2319 observed reflections $(I>3.00 \sigma(I))$, $R w=0.172$.

Acknowledgments We express our appreciation to Mr. K. Takeda and Mr. T. Iriguchi of Kumamoto University for measurement of the MS and NMR spectra.

\section{References and Notes}

1) “Chuyaku Daijiten,” ed. by Koso Shin Igakuin, Shanghai Kagaku Gijutsu Shuppansha, 1978, p. 2270.
2) Kouno I., Komori T., Kawasaki T., Tetrahedron Lett., 46, 4569-4572 (1973).

3) Kouno I., Noda N., Ida I., Sholichin M., Miyahara K., Komori T., Kawasaki T., Liebigs Ann. Chem., 1982, 306-314 (1982).

4) Sholichin M., Miyahara K., Kawasaki T., Heterocycles, 17, 251-257 (1982).

5) Sholichin M., Miyahara K., Kawasaki T., Chem. Pharm. Bull., 33, 1756-1759 (1985).

6) Lee S.-M., Chun H.-K., Lee C.-H., Min B.-S., Lee E.-S., Kho Y.-H., Chem. Pharm. Bull., 50, 1245-1249 (2002).

7) Adinolfi M., Corsaro M. M., Lanzetta R., Laonigro G., Mangoni L., Parrilli M., Phytochemistry, 26, 285-290 (1987).

8) Adinolfi M., Barone G., Belardini M., Lanzetta R., Laonigro G., Parrilli M., Phytochemistry, 23, 2091-2093 (1984).

9) Silayo A., Ngadjui B. T., Abegaz B. M., Phytochemistry, 52, 947—955 (1999).

10) Mãsterová I., Such'y V., Uhrín D., Ubik K., Grañcaiová Z., Bobovnick'y B., Phytochemistry, 30, 713-714 (1991).

11) Barone G., Corsaro M. M., Lanzetta R., Parrilli M., Phytochemistry, 27, 921-923 (1988)

12) Corsaro M. M., Lanzetta R., Mancino A., Parrilli M., Phytochemistry, 31, 1395-1397 (1992)

13) Mutanyatta J., Matapa B. G., Shushu D. D., Abegaz B. M., Phytochemistry, 62, 797-804 (2003).

14) Ono M., Masuoka C., Odake Y., Ikegashira S., Ito Y., Nohara T., Food Sci. Technol. Res., 6, 106-114 (2000).

15) Fukuhara K., Nakanishi I., Matsuoka A., Matsumura T., Honda S., Hayashi M., Ozawa T., Miyata N., Saito S., Ikota N., Okuda H., Chem. Res. Toxicol., 21, 282-287 (2008).

16) Adinolfi M., Barone G., Girdano F., Lanzetta R., Parrilli M., Tetrahedron, 46, 6565-6574 (1990).

17) Adinolfi M., Barone G., Corsaro M. M., Mangoni L., Tetrahedron, 44 4981-4988 (1988).

18) Altomare A., Cascarano G., Giacovazzo C., Guagliardi A., Burla M., Polidori G., Camalli M., J. Appl. Crystallogr., 27, 435 (1994).

19) CrystalStructure 3.6.0: Crystal Structure Analysis Package, Rigaku and Rigaku/MSC, 9009 New Trails Dr., The Woodlands, TX 77381, USA (2000-2004).

20) Watkin D. J., Prout C. K., Carruthers J. R., Betteridge P. W., "CRYSTALS Issue 10," Chemical Crystallography Laboratory, Oxford, U.K., 1996. 